\title{
Effectiveness of Alkali Water Consumption to Reduce Blood Sugar Levels in Diabetes Mellitus Type 2
}

\author{
Edy Siswantoro, Nasrul Hadi Purwanto, Sutomo \\ Department of Nursing, STIKES Dian Husada, Mojokerto, Indonesia \\ Email: edy.aryaboy@gmail.com
}

How to cite this paper: Siswantoro, E., Purwanto, N.H. and Sutomo (2017) Effectiveness of Alkali Water Consumption to Reduce Blood Sugar Levels in Diabetes Mellitus Type 2. Journal of Diabetes Mellitus, 7, 249-264.

https://doi.org/10.4236/jdm.2017.74020

Received: August 1, 2017

Accepted: October 8, 2017

Published: October 11, 2017

Copyright (c) 2017 by authors and Scientific Research Publishing Inc. This work is licensed under the Creative Commons Attribution International License (CC BY 4.0).

http://creativecommons.org/licenses/by/4.0/

\begin{abstract}
Background: Non-Communicable Diseases (NCDs) have become a public health problem, globally, regionally, nationally and locally. Non-Communicable Diseases (NCDs) that took a lot of attention was diabetes mellitus. In Indonesia diabetes mellitus is a serious threat to health development. Efforts developed to overcome the problems of diabetes mellitus type 2 is to apply four pillars of therapy namely education, nutrition therapy, physical activity and pharmacology. However, these efforts have not been able to achieve optimal results due to many obstacles encountered. One of the non-pharmacological treatments that can be utilized is to consume alkaline water to reduce blood sugar levels in diabetes mellitus type 2. Methods: The research design used was quasy experiment with pre-post control group design approach. The variables observed in this study were random blood sugar changes in people with diabetes mellitus type 2 prior to intervention and after intervention. Intervention is given over a period of 14 days. To measure the demand of drinking water on the respondents, the measurement was done using Water Drink Reminder - Hydro application. The alkaline water used in this study is alkaline water produced from Kangen Water Type SD501 Platinum Machine. Test analysis used is paired $t$ test to determine the effectiveness of alkaline water consumption to decrease random blood sugar level of diabetes mellitus type 2. To know the difference of effectiveness of alkaline water consumption to decrease of blood sugar level, it uses one way anova test with significance value $\alpha$ : 0.05 . Results: From result of the one way anova test with significance value $\alpha: 0.05$, we have got significance 0.039 . Since the significance probability value is $0.039<0.05$, the research hypothesis is accepted which means that there is a significant difference in the level of random blood sugar of diabetes mellitus type 2 performed by using four kinds of intervention of alkaline water treatment (Alkali Water PH 7.0, PH 8.0, PH 9.5 and PH 9.5 and $\mathrm{PH} 11.5$ )
\end{abstract}


for a period of 14 days. Conclusion: Support from health personnel and adherence to diabetes mellitus is required to utilize alkaline water as nonpharmacologic therapy to control blood sugar levels in people with type 2 diabetes mellitus. To achieve maximum results from nonfarmakologi therapy performed, people with diabetes mellitus type 2 should routinely consume antidiabetic drugs provided by health personnel and always strive for a healthy life.

\section{Keywords}

Diabetes Mellitus Type 2, Nonpharmacology Therapy, Alkaline Water

\section{Introduction}

Non-Communicable Diseases (NCDs) have become a public health problem, globally, regionally, nationally and locally. One of the Non-Communicable Diseases (NCDs) that took a lot of attention was diabetes mellitus. In Indonesia diabetes mellitus is a serious threat to health development [1]. Diabetes Mellitus is a disease characterized by the occurrence of hyperglycemia and carbohydrate, fat, and protein metabolism disorders associated with absolute or relative deficiencies of the work and/or insulin secretion. Symptoms are complained in people with Diabetes Mellitus is polydipsia, polyuria, polifagia, and weight loss [2]. Diabetes mellitus type 2 becomes a health problem that can lead to an increase in the amount of financing that must be spent by the community and government to solve the problem [3].

Global status report on NCD World Health Organization (WHO) in 2010 reported that $60 \%$ cause of death of all ages in the world is due to non-communicable diseases. Diabetes mellitus was ranked $6^{\text {th }}$ as the cause of death. Approximately 1.3 million people die from diabetes and $4 \%$ die before the age of 70 years. In Indonesia it is estimated that by 2030 it will have people with diabetes mellitus (people with diabetes) of 21.3 million people [1]. IDF (International Diabetes Federation) mentions in 2013 as many as 382 million people living with diabetes and by the year 2035 the number is expected to increase to 592 million people. It is estimated that of the 382 million people, 175 million of them have not been diagnosed, so threatened progressively develop into unconscious and without precautions [4].

Diabetes mellitus is a genetic and clinical metabolic disorder including heterogeneous with manifestations of loss of carbohydrate tolerance, if it has been fully developed clinically, diabetes mellitus is characterized by fasting and postprandial hyperglycaemia, atherosclerosis and microangiopathic vascular disease. Diabetes mellitus type 2 is a hyperglycemic disease caused by insensitivity of cells to insulin. Insulin levels may be slightly decreased or within the normal range. Because insulin is still produced by pancreatic beta cells, diabetes mellitus type 2 is considered non-insulin dependent diabetes mellitus. Diabetes mellitus type 2 is a metabolic disorder disease characterized by increased blood sugar due to decreased insulin secretion by pancreatic beta cells and/or insulin function 
disorder (insulin resistance) [2]. The prevalence of diabetes mellitus type 2 in women is higher than in men. Women are more at risk of diabetes because physically women have a greater chance of increased body mass index. Results of Basic Health Research in 2008 showed that the prevalence of diabetes mellitus in Indonesia increased to 57\%; in 2012 the incidence of diabetes mellitus in the world is 371 million people, where the proportion of diabetes mellitus type 2 is $95 \%$ of the world population who suffer from diabetes mellitus and only $5 \%$ of those suffering from type 1 diabetes mellitus [2].

The four main pillars of the management of diabetes mellitus type 2 are meal planning, physical exercise, hypoglycemic medicines, and counseling. Meal planning is a major component of successful management of diabetes mellitus type 2. Meal planning aims to help people with diabetes mellitus type 2 improve eating habits so as to control the levels of glucose, fat, and blood pressure. The success of meal planning depends on the behavior of people with diabetes mellitus type 2 in undergoing a given feeding suggestion. Noncompliance of patients in meal planning is one of the obstacles in the treatment of diabetes mellitus type 2 . WHO report data in 2003 showed that only $50 \%$ of patients with diabetes mellitus type 2 in developed countries adhere to treatment [5].

One of the nonpharmacological treatments that can be used by people with diabetes mellitus type 2 is to consume alkaline water with $\mathrm{PH}>7$. Results of research conducted by Kuwata Keijiroo [6], in patients given alkaline water for 1 month, from laboratory results obtained Sugar in blood and urine ranges from a ratio of $300 \mathrm{mg} / \mathrm{l}$ to $2 \mathrm{mg} / \mathrm{dc}$. There was a time in which the patient had undergone 5 to 6 blood test days and was detected within the normal range. Results also showed that even $11 / 2$ hours after eating, blood sugar and urine ratio was $100 \mathrm{mg} / \mathrm{dc}: 0 \mathrm{mg} / \mathrm{dc}$. This research is similar to the research done by Rosa Mistica [7], from the result of induction of metabolic disease in experimental animal, giving AIW (Alkaline Ionized Water) able to decrease glucose, total cholesterol and triglyceride level 11.15. Similar results conducted by Kim et al., AIW (Alkaline Ionized Water) are able to decrease abnormal glucose and blood lipid levels [8]. Nonpharmacological therapy as a companion of pharmacological therapy in diabetes mellitus type 2 should begin to be developed considering that the level of adherence of diabetes mellitus type 2 patients in experiencing therapy is still in the low category. The purpose of this study is to analyze the effectiveness of alkaline water consumption to decrease random blood sugar levels in people with diabetes mellitus type 2 .

\section{Methods}

\subsection{Study Design}

The research design used was quasy experiment with type pretest posttest control group design. Respondent of this research is people with diabetes mellitus type 2. This study was conducted from May 2017 to July 2017. 


\subsection{Subject Population and Sample Size}

This study involved 4 groups. Determination of respondent group by type of intervention to be given that is Group A (Intervention of alkaline water consumption $\mathrm{PH}$ 7.0/clean water), Group B (Intervention of alkaline water $\mathrm{PH} \mathrm{8.0),}$ Group C (Intervention of alkaline water consumption PH 9.5), and Group D (Intervention consumption of alkaline water combinations $\mathrm{PH} 9.0$ and 11.5). Each study group consisted of 7 respondents.

For the measurement of drinking water needs in each respondent in this study was measured using Water Drink Reminder - Hydro application. This is done to ensure that drinking water needs to be consumed by respondents in this study in accordance with their needs. The location of this research is in the work area Brangkal District Health Center Mojokerto. The research instrument used was observation sheet. The alkaline water used in this study is alkaline water produced from Kangen Water Type SD501 Platinum Machine. During the research activities, respondents were required to continue taking the drug diabetes mellitus (glibenclamide and metformin) provided by health personnel.

The limitations experienced by researchers in conducting this study is that researchers can not directly supervise the research respondents, especially in compliance to consume the amount of alkaline water that must be consumed by the respondent for a period of 1 day.

\subsection{Data Collecting Forms Used in the Study}

\subsection{Data Assessment}

The analysis test used paired t test to know effectiveness of alkaline water consumption to decrease random blood sugar levels in people with diabetes mellitus type 2. To know the difference of effectiveness of alkaline water consumption to decrease random blood sugar levels used one way anova test. The data was analyse using SPSS (Statistical Package for Social Science) 17.

\subsection{Ethical Concerns of the Study}

This study was approved by local ethics commission are derived from hospital institution Dr Wahidin Sudiro Husodo Mojokerto (047/RSU/EC/V/2017). Written official permissions were gained from informed consent was obtained from each participant. The patient were informed of the aim of the study and were assured that they had the right to refuse to participate or to leave the study whenever they wished.

\section{Result}

From the research results obtained data, most of the respondents of the study were men, as many as 20 respondents (71.4\%). For the obesity of the research results found that most of the respondents did not experience the obesity (normal weight) that is as much as 18 respondents (64.3\%), for work obtained most 
respondents aktrif work that is as much as 21 respondents (75\%). Most respondents were productive age ( $<50$ years) as many as 19 respondents $(67.9 \%)$, most of respondents had history of diabetes mellitus counted 25 respondents (89.3\%), for hypertension occurrence, most of respondent had prehypertension condition (TDS $=120-139 \mathrm{mmHg}$ ) as many as 15 respondents (53.6\%) (Table $1 \&$ Table 2).

1) Effectiveness of alkaline water ( $\mathrm{PH} 7.0 /$ clean water) consumption to decrease random blood sugar level in patient diabetes mellitus type 2

Table 1. Demographic data of research respondents.

\begin{tabular}{|c|c|c|c|}
\hline No & Demographic data & Frequency & Percentage \\
\hline \multirow{3}{*}{1} & Gender & & \\
\hline & - Man & 20 & 71.4 \\
\hline & - Women & 8 & 28.6 \\
\hline \multirow{4}{*}{2} & The incidence of obesity & & \\
\hline & - Normal & 18 & 64.3 \\
\hline & - Overweight & 9 & 32.1 \\
\hline & - Obesity & 1 & 3.6 \\
\hline \multirow{3}{*}{3} & Work activities & & \\
\hline & - Does not work active & 7 & 25.0 \\
\hline & - Works active & 21 & 75.0 \\
\hline \multirow{3}{*}{4} & Age of respondents & & \\
\hline & - $\quad$ Productive age & 19 & 67.9 \\
\hline & - Elderly & 9 & 32.1 \\
\hline \multirow{3}{*}{5} & History of diabetes mellitus & & \\
\hline & - No history of diabetes mellitus & 3 & 10.7 \\
\hline & - There is a history of diabetes mellitus & 25 & 89.3 \\
\hline \multirow{4}{*}{6} & The incidence of hypertension & & \\
\hline & - Prehypertension & 15 & 53.6 \\
\hline & - Hypertension stage 1 & 6 & 21.4 \\
\hline & - Hypertension stage 2 & 7 & 25.0 \\
\hline
\end{tabular}

Table 2. Results of data analysis (paired $t$ test) effectiveness of alkaline water consumption to decrease random blood sugar levels in patients with diabetes mellitus type 2 .

\begin{tabular}{ccccc}
\hline & $\begin{array}{c}\text { Group A (Intervention of } \\
\text { alkaline water consumption } \\
\text { PH 7.0/clean water) }\end{array}$ & $\begin{array}{c}\text { Group B (Intervention of } \\
\text { alkaline water PH 8.0) }\end{array}$ & $\begin{array}{c}\text { Group C (Intervention of } \\
\text { alkaline water } \\
\text { consumption PH 9.5) }\end{array}$ & $\begin{array}{c}\text { Group D (Intervention } \\
\text { consumption of alkaline water } \\
\text { combinations PH 9.0 and 11.5) }\end{array}$ \\
\hline Mean & -1.14286 & 2.57143 & 6.85714 & 14.85714 \\
Std. Deviasi & 1.75158 & 3.59894 & 2.67261 & 6.14894 \\
$\mathrm{t}$ & -0.652 & 1.890 & 6.788 & 6.393 \\
df & 6 & 6 & 6 & 6.001 \\
Sig. (2-tailed) & 0.538 & 0.108 & & 0.001 \\
\hline
\end{tabular}


From result of research, mean of random blood sugar of respondent before given intervention equal to 247.0000 with standard deviation equal to 7.83156 . After given intervention in the form of alkaline water ( $\mathrm{PH} 7.0 /$ clean water) for 14 days obtained mean random blood sugar of 248.1429 respondents and standard deviation of 9.51190 . From the correlation test results obtained the probability value (sig.) Of 0.010 with a correlation value of 0.875 . From result of paired $t$ test result got value $t$ count equal to -0.652 with probability value equal to 0.538 . Because the probability value obtained $0.538>0.05$ then concluded that the consumption of Alkaline Water ( $\mathrm{PH} 7.0 /$ clean water) during the period of 14 days is the same or no significant difference with the mean difference of random blood sugar equal to -1.14286 .

2) Effectiveness of alkaline water ( $\mathrm{PH} 8.0)$ consumption to decrease random blood sugar level in patient diabetes mellitus type 2

From result of research, mean of random blood sugar of responden before given intervention equal to 249.4286 with standard deviation equal to 8.75323 . After given intervention in the form of alkaline water consumption ( $\mathrm{PH} 8.0$ ) for 14 days obtained mean random blood sugar of 246.8571 respondents and standard deviation of 11.14194. From the correlation test results obtained the probability value (sig.) Of 0.001 with a correlation value of 0.963 . From result of paired $t$ test result got value $t$ count equal to 1.890 with probability value equal to 0.108 . Because the probability value obtained $0.108>0.05$ then concluded that consumption of Alkaline Water ( $\mathrm{PH}$ 8.0) during the period of 14 days is the same or no significant difference with the mean difference of random blood sugar equal to 2.57143 .

3) Effectiveness of alkaline water ( $\mathrm{PH} 9.5)$ consumption to decrease random blood sugar level in patient diabetes mellitus type 2

From result of research, mean of random blood sugar of responden before given intervention equal to 246.7143 with standard deviation equal to 9.72478 . After giving intervention in the form of alkaline water consumption ( $\mathrm{PH} 9.5$ ) for 14 days obtained mean random blood sugar of respondent equal to 239.8571 and standard deviation equal to 9.59911. From the correlation test results obtained a probability value (sig.) Of 0.001 with a correlation value of 0.962 . From result of paired $t$ test result got $t$ value equal to 6.788 with probability value equal to 0.001 . Because the probability value obtained $0.001<0.05$ then it is concluded that the consumption of Alkali Water ( $\mathrm{PH}$ 9.5) over a period of 14 days is not the same or significantly different with the mean difference of random blood sugar of 6.85714 .

4) Effectiveness of alkaline water (combination PH 9.5 and PH 11.5) consumption to decrease random blood sugar level in patient diabetes mellitus type 2

From result of research, mean of random blood sugar of responden before given intervention equal to 246.8571 with standard deviation equal to 10.66815 . After giving intervention in the form of alkaline water consumption (PH 9.5 and 
$\mathrm{PH}$ 11.5) for 14 days obtained mean of random blood sugar of respondent equal to 232.0000 and standard deviation equal to 12, 96, 148. From the correlation test results obtained the probability value (sig.) Of 0.009 with a correlation value of 0.882 . From result of paired t test result got value $t$ count equal to 6.393 with probability value equal to 0.001 . Because the probability value obtained $0.001<$ 0.05 then it is concluded that the consumption of Alkaline Water $(\mathrm{PH} 9.5$ and $\mathrm{PH} 11.5$ ) over a period of 14 days is not equal or significantly different with the mean difference of random blood sugar of 14.85714 .

5) Comparison of effectiveness of alkaline water consumption against random blood sugar decrease in diabetes mellitus type 2

From result of one way anova test with significance value $\alpha: 0.05$ got significance probability value equal to 0.039 . Because of the significance value of $0.039<$ 0.05 , the research hypothesis is accepted which means that there is a significant difference in the random blood sugar level of type 2 diabetes mellitus performed by using four kinds of intervention of alkaline water treatment ( $\mathrm{PH} 7.0 /$ clean water, $\mathrm{PH}$ 8.0, $\mathrm{PH} 9.5$ and combination $\mathrm{PH} 9.5$ and $\mathrm{PH} 11.5$ ) for a period of 14 days (Table 3 ).

\section{Discussion}

1) Effectiveness of alkaline water ( $\mathrm{PH} 7.0 /$ clean water) consumption to decrease random blood sugar in patient diabetes mellitus type 2

From the results of the research, it was found that the consumption of Alkaline Water ( $\mathrm{PH} \mathrm{7.0/clean} \mathrm{water)} \mathrm{for} 14$ days was not effective to reduce random blood sugar in patients with diabetes mellitus type 2 with a mean difference of random blood sugar of -1.14286 and probability value of 0.538 . Alkaline Water with $\mathrm{PH} 7.0$ or called clean water is the result of mineral water processing to produce a neutral, chlorine-free, rust-free and clear-colored water product. The benefits of alkaline water with $\mathrm{PH} 7.0$ can be used to take medication and prepare baby's milk, make cakes, bread and everything that needs water neutral with the best quality, clear and healthy [9]. Alkaline water product with PH 7.0 (clean water) produced by Kangen Water Type SD501 Platinum Machine, basically aims to produce water that is neutral and free from chemicals that may be contained in mineral water. Under these conditions alkaline water with $\mathrm{PH} 7.0$ (clean water) is ineffective when used as a nonpharmacological therapy to reduce random blood sugar levels of diabetes mellitus type 2 .

2) Effectiveness of alkaline water ( $\mathrm{PH} \mathrm{8.0)}$ consumption to decrease random

Table 3. Comparison of effectiveness of alkaline water consumption against random blood sugar reduction in diabetes mellitus type 2 .

\begin{tabular}{cccccr}
\hline & Sum of Square & df & Mean Square & F & Sig \\
\hline Between groups & 1159.143 & 3 & 386.381 & 3.255 & 0.039 \\
Within groups & 2848.571 & 24 & 118.690 & & \\
Total & 4007.714 & 27 & & &
\end{tabular}


blood sugar in patient diabetes mellitus type 2

From the results of the study, it was found that the consumption of alkaline water ( $\mathrm{PH}$ 8.0) during 14 days was ineffective in reducing random blood sugar in patients with diabetes mellitus type 2 with a mean difference of 2.57143 random blood sugar and probability value of 0.108 . Alkaline water ( $\mathrm{PH} 8.0)$ is a type of water that humans can consume to keep the body fit and healthy. Alkaline water with $\mathrm{PH} 8.0$ is perfect for routine consumption by anyone who wants to remain in optimal condition [10]. Mineral water with $\mathrm{pH}$ levels above 8 are alkaline/ alkaline useful to balance the excessive acidity of the body caused by a diet that is less balanced. Alkaline water PH 8.0 is generated from the ionization process to break down a series of water molecules making it more easily absorbed by the body's cells. The higher the number of water molecules that can be absorbed by the body the higher the opportunity for the human body to meet the needs of water molecules needed every day. In addition, the antioxidant content possessed by alkaline water, can help the body to counteract free radicals [11]. Alkaline water with PH 8.0 is basically a high water oxidant and able to assist the body in the process of increasing body immunity. From the results of observations made to respondents with interviewing techniques, as many as 5 respondents are not regular to consume alkali water in accordance with the instructions given by researchers. The amount of water sufficiency to be consumed daily can not be fulfilled by the respondents. The amount of water consumed by the respondents is possible to be one of the factors affecting the effectiveness of the alkaline water consumption with $\mathrm{PH} 8.0$ to decrease the (random blood sugar in the respondents.

3) Effectiveness of alkaline water ( $\mathrm{PH} 9.5$ ) consumption to decrease random blood sugar in patient diabetes mellitus type 2

The results showed that alkali water consumption ( $\mathrm{PH} 9.5$ ) during 14 days, effective to decrease random blood sugar in diabetes mellitus type 2 with difference of random blood sugar mean equal to 6.85714 and probability value equal to 0.001 . Alkaline water is a type of water that contains antioxidants. In alkaline water ( $\mathrm{PH}$ 9.5) generated from Kangen Water Type SD501 Platinum, exogenous (body-derived bodies obtained from the outside body) are needed by the body. Although it can produce its own antioxidants, the body tends to be more dependent on antioxidants coming from outside. In the chemical sense, antioxidants are electron-giving compounds. In the biological sense antioxidants are all compounds that can reduce the negative effects of oxidants, including inhibition and cessation of oxidative damage to a target molecule [12]. The definition of antioxidants according to the Panel on Dietary Antioxidants and Related Compounds of the Food and Nutrition Board is a food ingredient that significantly reduces the harmful effects of reactive oxygen compounds, reactive nitrogen compounds or both in normal physiological function conditions in humans. Diabetics require large amounts of antioxidant intake due to increased free radicals due to hyperglycemia [12]. These antioxidants will work by giving electrons 
to free radical molecules thus neutralizing the bad properties of free radicals. Antioxidants can help the body to overcome degenerative diseases. The disease is caused by unsaturated fatty acids in cell tissues stricken by free radicals resulting in the reaction between cells and produce peroxide compounds that damage cells [13]. The antioxidants found in alkaline water ( $\mathrm{PH} 9.5)$ can help the organs in the body, especially the pancreas to return to work optimally in producing insulin needed by the body.

4) Effectiveness of alkaline water (combination $\mathrm{PH} 9.5$ and $\mathrm{PH} 11.5$ ) consumption to decrease random blood sugar in patient diabetes mellitus type 2

The results showed that alkaline water consumption (combination PH 9.5 and PH 11.5) during 14 days, effective to decrease random blood sugar levels in diabetes mellitus type 2 with difference of random blood sugar mean equal to 14.85714 and probability value 0.001 . Alkaline water with $\mathrm{PH} 11.5$ or better known as strong water, is an alkaline water product that can be used as a substitute for mineral water commonly consumed daily. Alkaline water contains high antioxidants (up to $-500 \mathrm{mV}$ ). The combination of alkaline water with PH 9.5 and PH 11.5 (strong water) will further enhance the benefits of alkali water consumption itself. In addition to consumed as drinking water, alkaline water can also be used to brew coffee or drink tea. Alkaline water has micro cluster particles that are able to extract tea even at nominal temperatures. Heating alkaline water can decrease the antioxidant and $\mathrm{pH}$ which is owned by the alkaline water itself. However, a decrease in heated alkaline water is still able to have a positive impact on health including people with type 2 diabetes mellitus [10]. Diabetes mellitus is characterized by a decrease in the amount of insulin hormone capable of being produced by the pancreas. Hormone Insulin is the hormone responsible for regulating blood glucose levels as part of the body's metabolism. Insulin is produced by the body in the pancreas, this hormone is then released by the pancreatic beta cells, especially in response to increased blood glucose. When there is an increase in blood glucose levels, the absorption and metabolism of beta cells of the pancreas will be increased, and subsequently the secretion of insulin will also increase. The goal is to enter the blood glucose into the cells as a source of energy, energy reserves, and maintain normal levels of sugar in the blood. Under normal conditions, the pancreas releases only enough insulin to facilitate the absorption of glucose from the bloodstream into the cells. However, certain health conditions can cause the pancreas to produce and secrete too much insulin. High levels of insulin in the bloodstream are called hyperinsulinemia. This condition can cause a number of serious health problems. Hyperinsulinemia also causes metabolic syndrome, a disorder characterized by high insulin levels, obesity, high lipid levels and insulin resistance. Diabetes mellitus occurs when excessive production of insulin lasts so long that it causes damage to beta cells in the pancreas. In this considium insulin production will decrease and blood glucose levels rise, always above norml and this is called diabetes. High insulin le- 
vels can also cause elevated levels of male hormones in women, leading to polycystic ovary syndrome (PCOS). In the absence of insulin, the body is unable to utilize glucose as energy in the cell. As a result, glucose remains in the bloodstream and can cause high blood sugar, known as hyperglycemia. Chronic hyperglycemia is a high blood sugar lasting long, and this is a characteristic of diabetes mellitus. If this condition is not treated, it can cause severe complications, such as damage to the nervous system, eyes, kidneys and limbs. In severe cases, insulin deficiency and decreased ability to use glucose as an energy source can cause fat dependence as the only source of energy. This breakdown of fat can release the ketone into the bloodstream, which can lead to a serious condition called ketoacidosis.

The development of nonpharmacological therapy as a companion of pharmacological therapy is one of the methods developed for the success of therapy to people with diabetes mellitus type 2. One way that can be done is to consume alkali water regularly. Khushboo [14] argues that alkaline water is water that has a subtle nature, energy source, has the ability to cleanse the body and is a combination of unique water characteristics. This water is also microscopic with unparalleled absorption ability. Alkaline water is capable of providing the electrons needed by the body to destroy harmful free radicals present in the body. Ionized alkaline water can remove active oxygen and protect DNA from oxidative damage. The ideal compound for the removal of active oxygen is active hydrogen. This active hydrogen is able to protect and prevent oxidative damage and prevent the occurrence of cancer [15]. The results showed that alkaline water consumption with $\mathrm{pH} 9.5$ and $\mathrm{PH} 11.5$ was proven effective for lowering random blood glucose level in diabetes mellitus type 2. Alkaline water working system (missed water PH 9.5 and $\mathrm{PH} 11.5$ ) is to clean the disease that is in the body or better known by the public with a detox system. Detox is a process that occurs in the body to remove toxins that exist in the body. The impact that appears on all respondents in this study is frequent urination. Research respondents say that after 2 - 3 days of consuming their alkaline water it is often to the bathroom to urinate. This is a concern to the respondents themselves. However, the researchers explained to the respondents that the urination effect is a common effect when consuming alkaline water because basically alkaline water that comes in works as a detox. Furthermore alkaline water will seek to improve the immunity possessed by the body. Alkaline water is actually not used for healing but tends to be used as a trigger of the organs in the body to improve the immune system owned. Improved immune system will greatly help the body, especially in the pancreas in producing insulin. The most important thing to note about alkaline water is alkaline water is not allowed to be consumed along with food or medicine provided by doctors or health workers. The use of alkaline water simultaneously with medication or prescription/nakes will decrease the effects of the drug consumed itself. To obtain maximum results in the use of alkaline water in lowering random blood glucose level is to combine pharmacological therapy 
with nonpharmacological therapy.

5) Comparison of effectiveness of alkaline water consumption against random blood sugar decrease in diabetes mellitus type 2

From result of one way anova test with significance value $\alpha$ : 0.05 got significance probability value equal to 0.039 . Because the significance probability value is $0.039<0.05$, the research hypothesis is accepted which means there is a significant difference in the level of random blood sugar level of diabetes mellitus type 2 performed using four kinds of alkaline water treatment ( $\mathrm{PH} 7.0 /$ clean water, $\mathrm{PH}$ 8.0, $\mathrm{PH} 9.5$ and combination $\mathrm{PH} 9.5$ and $\mathrm{PH} 11.5$ ) for a period of 14 days.

The results of this study are similar to those of Kim et al. [8]. From the results of testing the effectiveness of ERW (electrolyzed Reduced Water) in the group of mice induced by STZ (streptozotocin) showed that ERW (electrolyzed Reduced Water) significantly reduced blood glucose levels and improve glucose tolerance in diabetic mice, both models mice that were genetically diabetic As well as those given STZ toxin (streptozotocin) so as to have diabetes. In addition, ERW (Electrolyzed Reduced Water) can also significantly increase blood insulin levels in mice that are genetically diabetic. Improvement in blood sugar levels is estimated to increase insulin sensitivity and insulin release from the pancreas. These data suggest that ERW (Electrolyzed Reduced Water) can serve as an effective oral anti-diabetic drug. Research Kajiyama et al., states that oxidative stress is widely recognized because it is associated with a variety of disorders including diabetes, hypertension, and atherosclerosis. One of the therapies that can be used to overcome this problem is by increasing the intake of hydrogen-rich water (alkaline water). Hydrogen-rich water intake was associated with a significant reduction in levels of low-density lipoprotein cholesterol (LDL) [16]. The results of the study show that supplementation with hydrogen-rich water may have a beneficial role in the prevention of type 2 diabetes mellitus and insulin resistance. Research carried Feng et al [17], showed that mice induced by STZ (streptozotocin) and given therapy alkaline water (water rich in hydrogen) can lower oxidative stress, increase the activity of antioxidant enzymes and levels of synaptophysin and BDNF (Brain Derived neurotrophin Factor ). Based on the inhibition of oxidative stress and anti-oxidative enzymes arrangement, it can be concluded that concluded that alkaline water (water rich in hydrogen) is a potentially valuable therapeutic modalities for the treatment of DR (diabetic retinopathy).

Diabetes Mellitus can be experienced by all levels of society, both in terms of economic low, middle, upper, and also in terms of age. Productive age (20 - 50 years) and elderly ( $>50$ years) can be a type 2 diabetes mellitus. In general, humans undergo physiological changes with age. Decreased function of organs of the body began to decline rapidly after the age of 40 years. Diabetes meliitus often appears after a person entering the age of prone, especially after the age of 45 years in those who overweight, so that his body is insensitive to insulin again. 
The existing theory suggests that people with age $\geq 45$ years have an increased risk of developing diabetes mellitus and glucose intolerance caused by degenerative factors that decrease body function, especially the ability of $\beta$ cells in producing insulin [18]. Alkaline water basically refers to the $\mathrm{PH}$ level that is owned by water. The PH level (Potential of Hydrogen) is the degree of acidity used to express the level of acidity or alkalinity possessed by a solution. $\mathrm{PH}$ is defined as the soluble hydrogen ion $(\mathrm{H}+)$ activity kologarithm. The $\mathrm{PH}$ level is a number that measures how acid or base a substance is on a scale of 0 to 14. For example, something with a $\mathrm{PH}$ of 1 will be very acidic, and something with a $\mathrm{PH}$ of 13 will be very alkaline. Alkaline water has a higher PH level than regular drinking water. Therefore, some supporters of alkaline water can neutralize acid in the body. Normal drinking water generally has a neutral PH 7. Alkaline water usually has a $\mathrm{PH}$ of 8 or 9. Alkaline water consumption still invites a lot of controversy among health professionals. This is a natural occurrence because health professionals believe that pharmacological therapy is the best therapy that can be given to patients such as diabetes mellitus type 2. Health professionals believe that OHA (Oral Hypoglycemic Agents) is a therapy Pharmacologically best for people with diabetes mellitus. Until now there are known five kinds of marketed OHA (Oral Hypoglycemic Agents), each kind of OHA (Oral Hypoglycemic Agents) has different chemical arrangement and how to lower glucose that is different. Some stimulate the pancreas to produce more insulin, others work to reduce insulin resistance, while others inhibit the absorption of carbohydrates from the gut. Patients with diabetes mellitus type 2 , at the onset of treatment usually use one type of OHA (Oral Hypoglycemic Agents), but to more effectively lower blood glucose, sometimes it takes more than one kind of OHA (Oral Hypoglycemic Agents).

Technological developments and progress are also experienced by the world of health, one of which is the management of therapy in people with diabetes mellitus type 2. One of the most reliable parameters to be a successful indicator of controlling blood glucose levels is the level of glycosylated hemoglobin (HbAlc) can be used as an indicator of the assessment of blood glucose control in diabetic patients in the last 2 - 3 months. Management of patients with diabetes mellitus type 2 is known as four important pillars in controlling the course of disease and complications. The four pillars are education, nutrition therapy, physical activity and pharmacology [19]. The education provided is an understanding of the course of the disease, the importance of disease control, the complications that arise and the risks, the importance of drug intervention and the monitoring of blood glucose, how to treat hypoglycemia, the need for regular physical exercise, and how to use health facilities. Educating the patient aims to enable the patient to control blood sugar, reduce complications and improve self-care abilities. Good eating planning is an essential part of total diabetes management. A balanced diet will reduce the workload of insulin by eliminating the work of insulin converting sugar into glycogen. The success of this therapy involves doctors, nurses, nutritionists, the patient himself and his family. Daily 
physical activity and regular physical exercise (3 - 4 times a week for approximately 30 minutes), is one of the pillars in the management of diabetes mellitus type 2. Daily activities such as walking to the market, using stairs, gardening should still be done Physical exercise in addition to maintaining fitness can also lose weight and improve insulin sensitivity, thus improving blood glucose control. Physical exercises are recommended in the form of aerobic physical exercise such as walking, cycling, jogging, and swimming. Physical exercise should be tailored to the age and physical fitness status. For those who are relatively healthy, the intensity of physical exercise can be improved, while those already complicated with diabetes mellitus may be reduced [8]. Pharmacological therapy is given along with dietary and physical exercise (healthy lifestyle). Pharmacologic therapy consists of oral and injectable drugs. Oral hypoglycemic drugs, Based on the way they work, Oral hypoglycemic drugs are divided into 5 groups: Trigger insulin secretion sulfonylurea and glinid. Increased sensitivity to insulin metformin and thiazolidindion. Gluconeogenesis inhibitors. Glucose absorption inhibitor: DPP-IV alpha-inhibitor glucosidase inhibitor [20].

Consuming ionized water increases the alkalinity in the body, in addition to the negative use of ORP (Oxidation Reduction Potential), neutralizes free radicals in the body. There is another important aspect embedded in negative and reduced electrically charged water, namely low micro clustering (having small particle size) of water molecules. This process reduces the surface tension of the water and makes it soluble and absorbed. Typically, potable water ranges between $\mathrm{pH} 7.0$ - $\mathrm{pH}$ 9.5. This builds up a high alkaline nature in the body that will create a "healing process" called the Herxheimer reaction. This is a good thing and shows that alkaline water "fights" against the disease in the body caused by the nature of the acid. Depending on the severity of a person's illness or the degree of acidic nature, this "reaction" usually lasts relatively briefly. Common symptoms are usually a sense of lethargy, exhaustion, headache, slight nausea, etc. If this reaction is felt too strongly on you, it is advisable to reverse the $\mathrm{PH}$ but increase the drinking water intake into more. As a result, the body will get rid of toxic (toxic substances) that have been "stirred", while reducing (a little) $\mathrm{PH}$ height level will slow down the stimulation process of toxins in the body. Consumption of alkaline water with PH 9.5 and PH 11.5 will help the body to be in optimal condition and will ultimately increase the body immunity that is able to trigger the pancreas to re-optimum work to produce insulin. The consumption of alkaline water with $\mathrm{PH} 9.5$ as well as a combination of alkaline water $\mathrm{PH}$ 9.5 and strong alkaline water PH 11.5 have been shown to be effective in reducing random blood sugar level in diabetes mellitus type 2 . To obtain the most effective results it is advisable to Performing a combination when consuming alkaline water, between alkaline water PH 9.5 and strong alkaline water PH 11.5. However, if it does not have sufficient financing to consume alkaline water $\mathrm{PH}$ 9.5 and strong alkaline water $\mathrm{PH} 11.5$ people with diabetes mellitus type 2 can consume alkaline water with $\mathrm{PH} 9.5$ on a regular basis. 


\section{Conclusions}

1) From the results of the research, it was found that the consumption of $\mathrm{Al}$ kaline Water ( $\mathrm{PH} 7.0 /$ clean water) for 14 days was not effective to reduce random blood sugar in patients with diabetes mellitus type 2 with a mean difference of random blood sugar of -1.14286 and probability value of 0.538 .

2) From the results of the study, it was found that the consumption of alkaline water ( $\mathrm{PH} \mathrm{8.0)}$ during 14 days was ineffective in reducing random blood sugar in patients with diabetes mellitus type 2 with a mean difference of 2.57143 random blood sugar and probability value of 0.108 .

3) The results showed that alkali water consumption (PH 9.5) during 14 days, was effective to decrease random blood sugar in diabetes mellitus type 2 with difference of random blood sugar mean equal to 6.85714 and probability value equal to 0.001 .

4) The results showed that alkaline water consumption (combination PH 9.5 and $\mathrm{PH}$ 11.5) during 14 days, was effective to decrease random blood sugar levels in diabetes mellitus type 2 with difference of random blood sugar mean equal to 14.85714 and probability value 0.001 .

5) There was a significant difference in the level of random blood sugar level of diabetes mellitus type 2 performed using four different interventions of alkaline water treatment (PH 7.0/clean water, $\mathrm{PH}$ 8.0, $\mathrm{PH} 9.5$ and combination $\mathrm{PH}$ 9.5 and $\mathrm{PH} 11.5$ ) over a period of 14 days.

\section{Acknowledgements}

This study received support and financing from the Ministry of Research and Technology Higher Education Republic of Indonesia through the National Competitiveness Program - Research Scheme Lecturer Beginners with SP DIPA042.06.1.401516/2017, December 06, 2016.

\section{References}

[1] Kemenkes, R.I. (2013) Diabetes Melitus Penyebab Kematian Nomor 6 di Dunia: Kemenkes Tawarkan Solusi CERDIK Melalui Posbindu. [Diabetes Mellitus Cause of Death Number 6 in the World: Ministry of Health Offer CERDIK Solution through Posbindu.].

http://www.depkes.go.id/article/view/2383/diabetes-melitus-penyebab-kematian-no mor-6-di-dunia-kemenkes-tawarkan-solusi-cerdik-melalui-posbindu.html

[2] Apriani, S., Raksanagara, A.S. and Sari, C.W.M. (2015) Pengaruh Program Edukasi Dengan Metode Kelompok Terhadap Perilaku Perawatan Diri Pasien Diabetes Melitus Tipe 2. [Effect of Educational Program with Group Method of Self Care Behavior Diabetes Mellitus Type 2 Patient]. http://ejournal.stikesborromeus.ac.id/file/jurnal\%203.pdf

[3] Yaturu, S. (2011) Obesity and Type 2 Diabetes. Journal of Diabetes Mellitus, 1, 79-95. https://doi.org/10.4236/jdm.2011.14012

[4] Kemenkes, R.I. (2014) Situasi dan Analisis Diabetes. Jakarta; Pusat Data Dan Informasi Kementerian Kesehatan Republik Indonesia. [Situation and Analysis of Diabetes. Jakarta; Data and Information Center Ministry of Health Republic of In- 
donesia].

http://www.depkes.go.id/resources/download/pusdatin/infodatin/infodatin-diabetes .pdf

[5] Al Tera, B.H. (2011) Determinan Ketidakpatuhan Diet Penderita Diabetes Melitus Tipe 2 (Studi Kualitatif Di Wilayah Kerja Puskesmas Srondol Kota Semarang). [Determinants of Non-Adherence Diet Diabetes Mellitus Type 2 (Qualitative Studies in the Work Area Puskesmas Srondol Semarang City)].

http://eprints.undip.ac.id/32591/1/393_Banu_Hanifah_Al_Tera_G2C007014.pdf

[6] Hayakawa, T. (2000) Scientific Research Studies on Ionized Alkaline Water. http://www.americanaci.org/uploads/8/1/2/0/8120997/medresearchaiw.pdf

[7] Ignacio, R.M.C., Joo, K.-B. and Lee, K.-J. (2012) Clinical Effect and Mechanism of Alkaline Reduced Water. Journal of Food and Drug Analysis, 20, 394-397.

[8] Kim, M.J. and Kim, H.K. (2006) Anti-Diabetic Effects of Electrolyzed Reduced Water in Streptozotocin-Induced and Genetic Diabetic Mice. Life Sciences, 79, 2288-2292. https://doi.org/10.1016/j.lfs.2006.07.027

[9] Anonim (2014) Manfaat Kangen Water. [Benefit of Kangen Water]. http://www.kangenwatercenter.com/kelebihankangenwater.php

[10] Anonim (2014) Lima Jenis Air Yang Bermanfaat. [Five Useful Water Types]. http://enagickangenwaterindonesia.com/manfaat-kangen-water

[11] Anonim (2015) Liquo8; Ionized Mineral Water. https://www.liquo8.com/

[12] Setiawan, B. and Suhartono, E. (2005) Stres oksidatif dan peran antioksidan pada diabetes melitus. [Oxidative Stress and the Role of Antioxidants in Diabetes Mellitus]. Majalah Kedokteran Indonesia, 55, 87-90.

[13] Kumalaningsih, S. (2006) Antioksidan Alami-Penangkal Radikal Bebas, Sumber, Manfaat, Cara Penyediaan dan Pengolahan. [Antioxidant Natural-Free Radical Abatement, Source, Benefits, Ways of Supply and Processing]. Trubus Agrisarana, Surabaya.

[14] Khushboo, P., Lipsa, S., Priti, Y., Divya, P., Kaenat, S., Shivani, P., et al. (2014) Alkaline Water: The Disease Fighting Water. World Journal of Pharmaceutical Research, 3, 3845-3853.

[15] Wan-Jun, Z., Masaaki, N., Takefumi, M., Kiyotaka, H., Hiroyuki, T., Junichiro, K., et al. (2013) Amelioration of Cardio-Renal Injury with Aging in Dahl Salt-Sensitive Rats by H2-Enriched Electrolyzed Water. Medical Gas Research, 3, 1-8.

[16] Kajiyama, S., Hasegawa, G., Asano, M., Hosoda, H., Fukui, M., Nakamura, N., Adachi, T., et al. (2008) Supplementation of Hydrogen-Rich Water Improves Lipid and Glucose Metabolism in Patients with Type 2 Diabetes or Impaired Glucose Tolerance. Nutrition Research, 28, 137-143.

[17] Feng, Y., Wang, R., Xu, J., Sun, J., Xu, T., Gu, Q. and Wu, X. (2013) Hydrogen-Rich Saline Prevents Early Neurovascular Dysfunction Resulting from Inhibition of Oxidative Stress in STZ-Diabetic rats. Current Eye Research, 38, 396-404. https://doi.org/10.3109/02713683.2012.748919

[18] Betteng, R. (2014) Analisis Faktor Resiko Penyebab Terjadinya Diabetes Melitus Tipe 2 Pada Wanita Usia Produktif Dipuskesmas Wawonasa. [Risk Factors Analysis Causes of Type 2 Diabetes Mellitus in Productive Age Women Diposkesmas Wawonasa]. Jurnal e-Biomedik, 2.

[19] Putra, I.W.A. and Berawi, K.N. (2015) Empat Pilar Penatalaksanaan Pasien Diabetes Mellitus Tipe 2. [Four Pillars of Patient Management Type 2 Diabetes Mellitus]. 
Jurnal Majority, 4, Nomor 9.

[20] American Diabetes Association (2014) Diagnosis and Classification of Diabetes Mellitus. Diabetes Care, 37, S81-S90. https://doi.org/10.2337/dc14-S081 